
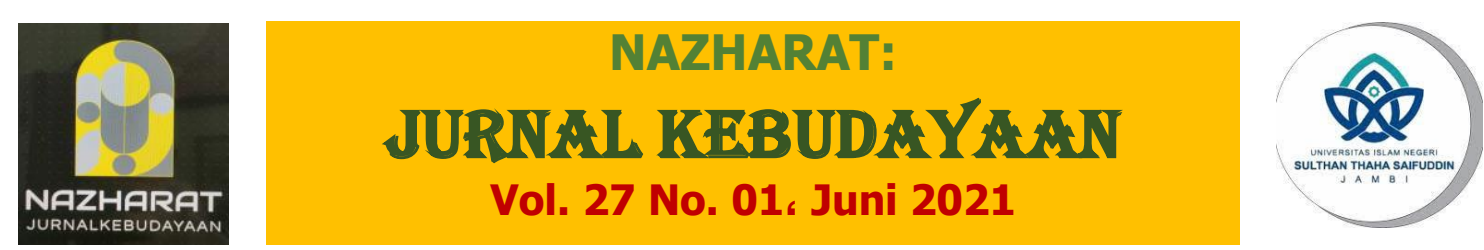

\title{
JEMBATAN PENYEBERANGAN PERADABAN ISLAM KE EROPA
}

\section{Mami Nofrianti}

IAIN Batusangkar

Jl. Sudirman No.137 Lima Kaum Batusangkar

e-mail: maminofrianti@iainbatusangkar.ac.id

Penyeberangan peradaban Islam ke Eropa terjadi melalui Andalusial Spanyol, Sisilia dan melalui Perang Salib. Lebih dari delapan abad Umat Islam berkuasa di Spanyol dan telah mencapai masa kejayaannya di sana. Walaupun dalam bidang politik terjadi gelombang turun naik, dinasti silib berganti dan perebutan kekuasaan sering terjadi, namun dalam bidang intelektual dan peradaban mencapai prestasi yang gemilang. Sangat banyak prestasi yang dicapai babkan pengarubnya membawa Eropa dan Dunia kepada kemajuan yang lebih kompleks. Yang paling berpengaruh di Eropa adalah pemikiran Ibn Rusyd yang melepaskan belenggu Taklid dan menganjurkan kebebasan berfikir. Pengaruh pemikiran Ibn Rusyd sangat besar di Eropa, sehingga muncul gerakan Averroeisme (Ibn Rusyd-isme). Walaupun pibak gereja menolak pemikiran rasional tersebut namun berawal dari gerakan inilah pada abad ke $16 \mathrm{M}$ labirlah reformasi dan pada abad ke 17 M labir pula rasionalisme di Eropa. Begitu juga dengan Pulau Sisilia di masa Dinasti Kalbiyah mengalami kemajuan dalam segala bidang. Sarjana-sarjana muncul dari berbagai bidang ilmu. Perang Salib yang berlangsung lebih kurang dua abad juga telah membawa Eropa ke dalam kontak langsung dengan Dunia Islam. Kemajuan orang-orang Timur menjadi daya dorong yang besar bagi pertumbuban intelektual Eropa Barat dan menambah pentingnya posisi Eropa termasuk di lapangan perniagaan, perdagangan dan perindustrian. Difusi kebudayaan Barat dan Timur pada masa Perang Salib inilah pada akbirnya juga menjadi landasan bagi terjadinya renaissance (kebangkitan kembali) di Eropa, reformasi, rasionalisme dan Pencerahan (Aufklarung) yang pada akbirnya membawa Eropa kepada zaman kemajuan.

\section{Keywords : Jembatan, Penyeberangan, Peradaban Islam, Eropa}

\section{INTRODUCTION (مقدمة)}

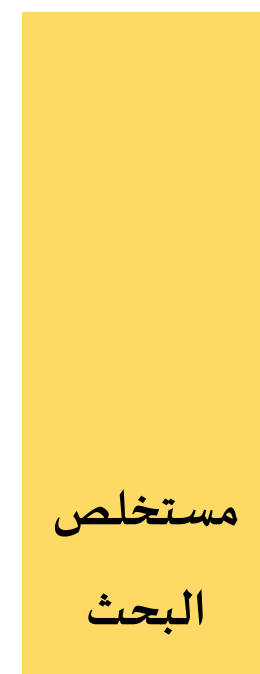

Abstract
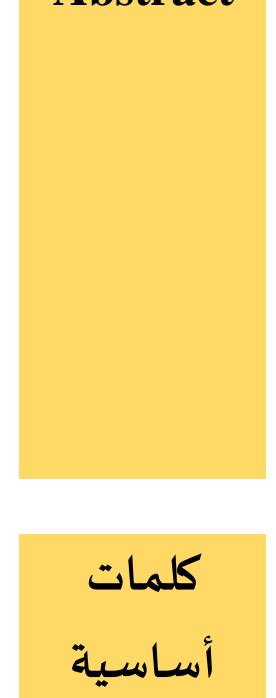

Keyword

Pada zaman keemasan Islam telah terjadi kontak Islam dengan Barat. Kontak tersebut sangat jauh berbeda dengan apa yang terjadi pada zaman modern sekarang. Karena hal itu mengakibatkan Barat menjadi maju. Pada zaman keemasan Islam, Islam 
telah mencapai puncak kebudayaan dan peradaban, sedangkan Barat masih tenggelam dalam kebodohan dan kegelapan. Ketika itu Cordova sangat maju, kreatif dan dinamis serta telah banyak buku-buku yang dikarang oleh ilmuwan muslim. Gedung-gedung sangat megah, telah terciptanya karya seni yang bernilai tinggi, mereka bahkan sudah menguasai suatu peradaban yang istimewa. Setelah terjadi kontak Islam dengan Barat, maka terjadi perubahan yang besar di Barat. Hearsnsaw pernah berkata bahwa saat pertama kali Eropa melancarkan serangan terhadap Umat Islam pada perang Salib, Eropa terkejut dengan Peradaban yang dimiliki oleh Umat Islam ketika itu (Ahmad Syalabi, 1997: 204). Peradaban Islam ternyata lebih maju dari pada peradaban Eropa. Dari sinilah Eropa menyerap ilmu pengetahuan dan teknologi dari ilmuwan muslim. Eropa berhutang budi kepada Islam. Kemajuan yang telah Eropa peroleh tidak terlepas dari konstribusi Khazanah Peradaban Islam. (Fatah Syukur, 2010: 159). Setelah gencatan senjata dan perdamaian antara muslim dan Eropa disepakati pasca Perang Salib, sejak itulah Eropa dan muslim hidup berdampingan terjadi interaksi-interaksi sosial hingga akhirnya peradaban Islam mewarnai peradaban Eropa. Tidak dapat dipungkiri bahwa kemajuan Peradaban Eropa diperoleh dari transfer ilmu pengetahuan, budaya, dan teknologi umat Islam. Penyeberangan peradaban Islam ke Barat tersebut melalui tiga jalur yang akan penulis uraikan dalam tulisan ini yakni melalui Andalusia/ Spanyol, melalui Sisilia dan melalui Perang Salib yang terjadi lebih kurang dua abad. Dalam Tulisan ini penulis akan menguraikan bagaimana peran Andalusia dan Sisilia ketika dikuasai Umat Islam, begitu juga dengan peristiwa Perang salib yang pada akhirnya juga menjadi jembatan penyeberangan Ilmu pengetahuan Islam ke wilayah Eropa.

\section{THEORITICAL FRAMEWORK (نظريات)}

In Islamic perspectives, leadership has the same definition such as another perspective. However, there is any differentiate from another perspective which is the Islamic roots of leadership generally exist in the primary sources of Shari'ah (Qur'an and Sunnah) in addition to the practices of the early Muslims (Ahmad \& Ogunsola, 2011; Almoharby \& Neal, 2013). Where the Qur'an is the holy book of the religion of Islam, and the Sunnah describes the exemplary life of Prophet Mohammad (PBUH), largely understood through the narration of his words and deeds, as known the Hadiths (Abdallah, Çitaku, Waldrop, Zillioux, Preteni, \& Khan., 2019). 


\section{METHOD (طريقة \منهج البحث)}

Penelitian ini merupakan penelitian kualitatif yang mendiskripsikan semua data yang ditemukan melalui pendekatan kepustakaan (Library Research) dengan mengumpulkan, membaca dan menelaah buku-buku yang ada kaitannya dengan pembahasan ini. Sumber primer dari penelitian ini adalah buku-buku Sejarah Peradaban Islam yang berkaitan dengan pembahasan yang dibahas. Penelitian ini tidak menetapkan suatu lokasi sebagai tempat penelitian karena kajiannya cenderung pada naskah teks. Pada tahap ini dilakukan kegiatan yang berupa mengolah data yang diperoleh dari dokumen, kemudian akan disusun ke dalam sebuah penelitian. Hasil analisis tersebut dituangkan dalam bentuk laporan penelitian secara deskriptif.

\section{FINDINGS \& DISCUSSION (بحث ومناقشاة)}

Perkembangan Peradaban Islam di Eropa hingga saat ini tidak terlepas dari sumbangan ilmu pegetahuan Islam pada masa periode Klasik. Beberapa saluran yang membawa peradaban Islam sehingga berpengaruh di Eropa adalah Andalusia, Sisilia dan Perang Salib. Di samping itu, tidak bisa kita lupakan peranan Perdagangan dari Kaum Muslimin antara negara-negara Islam sampai ke Eropa dan juga sampai ke Asia.

\section{Spanyol/Andalusia}

\section{a. Masuknya Islam ke Andalusia/Spanyol}

Andalusia atau Andalus adalah tanah Spanyol di tambah dengan Portugal sekarang. Kata-kata Andalus diperkenalkan oleh orang-orang Arab setelah menduduki Spanyol dan Portugal sekarang. Andalus diambil dari kata-kata vandal, nama bangsa yang bertempat tinggal disitu (Drs. Abdullah Salim, 1980:4).

Spanyol merupakan sebuah wilayah yang pernah ditaklukkan oleh Islam. Keadaan Spanyol sebelum keadatangan Islam pada umumnya tidak jauh berbeda dengan daerah-daerah lainnya di Eropa, yang mana masih dalam keterbelakangan dan kebodohan. Ketika Islam masuk ke wilayah Spanyol, Spanyol mengalami perkembangan pesat dari segi peradaban maupun pendidikan karena didukung oleh kondisi wilayahnya yang subur sehingga menghasilkan ekonomi yang baik dan menghasilkan pemikir-pemikir hebat. 
Munculnya orang-orang Islam di Eropa di awali dengan kehadiran orang-orang Islam di wilayah tersebut yang mana gerbang dari masuknya Islam ke benua Eropa tersebut adalah wilayah Spanyol itu sendiri. Sebagaimana yang terdapat dalam buku-buku sejarah bahwa masuknya islam ke wilayah Andalusia terjadi pada masa kekuasaan daulah bani Umayyah yang mana ketika itu yang menjadi khalifah adalah Walid ibn Abdul Malik. Masa pemerintahan Walid Ibn Malik, khalifah dari pemerintahan daulah Bani Umayyah, yang diangkat menjadi amir di wilayah Afrika Utara ketika itu adalah Musa bin Nushair.

Ada tiga pahlawan Islam yang dikatakan paling berjasa dalam penaklukan wilayah Spanyol: Tharif Ibn Malik, Tariq Ibn Ziyad dan Musa Ibn Nushair. Musa Ibn Nushair sebagai Gubernur Afrika Utara ketika Utara pada waktu itu dan mengirimkan Tharif Ibn Malik sebagai mata-mata dan perintis. Karena keberhasilan Tarif, Musa ibn Nushair kembali mengirimkan pasukan yang lebih besar lagi ke Spanyol, dan hingga akhirnya Musa Ibn Nushair sendiri tertarik untuk melibatkan diri dalam penaklukan wilayah Spanyol.

Setelah masuknya Islam, masa pemerintahan Islam di Andalusia silih berganti dimulai dari masa Kewalian, masa Keamiran, masa Kekhalifahan, Muluk at-thawaif, masa Daulah Murabhitun, Daulah Muwahhidun dan Masa Daulah Bani Ahmar sebagai pusat pemerintahan Islam terakhir di wilayah Granada.

\section{b. Kemajuan Peradaban Muslim Spanyol}

Lebih dari delapan abad Umat Islam berkuasa di Spanyol (92-897 H/ 7111492 M), umat Islam telah mencapai masa kejayaannya disana. Walaupun dalam bidang politik terjadi gelombang turun naik, dinasti silih berganti dan perebutan kekuasaan sering terjadi, namun dalam bidang intelektual dan peradaban mencapai prestasi yang gemilang. Sangat banyak prestasi yang dicapai bahkan pengaruhnya membawa Eropa dan Dunia kepada kemajuan yang lebih kompleks.

Muslim Spanyol telah membuka lembaran baru sejarah intelektual Islam, bahkan sejarah intelektual agama. Mereka bukan hanya sebagai penyulut pelita kebudayaan dan peradaban maju melainkan juga sebagai media penghubung 
ilmu pengetahuan dan filsafat yang telah berkembang sebelumnya. Spanyol pada masa pemerintahan Umat Islam menjadi pusat peradaban yang tertinggi.

Spanyol merupakan negeri yang subur sehingga mendatangkan penghasila ekonomi yang tinggi sehingga banyak menghasilkan para pemikir. Masyarakat Spanyol Islam adalah masyarakat yang terdiri dari komunitaskomunitas Arab (Utara dan Selatan), al Muwalladun (orang-orang Spanyol yang masuk Islam), Barbar (Umat Islam yang berasal dari Afrika Utara), al Shaqalibah (penduduk antara Kontanstinopel dan Bulgaria yang menjadi tawanan Jerman dan dijual kepada penguasa Islam untuk dijadikan tentara bayaran), Yahudi, Kristen, Muzareb yang berbudaya Arab dan Kristen yang masih menentang ajaran Islam. Semua komunitas itu, kecuali yang terakhir, memberikan saham intelektual terhadap terbentuknya lingkungan budaya Andalus, yang melahirkan kebangkita ilmiah baik dalam bidang 'Ulum al Naqliyah maupun 'Ulum al 'Aqliyah, perkembangan sastra dan pembangunan Fisik di Spanyol.

Dalam bidang Fiqh, penduduk Spanyol Islam dikenal sebagai penganut Mazhab al Malikiyah yang diperkenalkan oleh Ziyad ibn 'Abd al Rahman, dan sebagian kecilnya ada yang menganut Mazhab Al Zhahiriy yang diperkenalkan oleh al Balluthiy. Tokoh-tokoh fiqh yang terkenal adalah Ziyad ibn 'Abd al Rahman, Yahya al Mashmudiy, Al Balluthiy, Ibn al Fakhkhar, Al Qabbariy, Ibn Siraj, Ibn Hazm, Ibn Rusyd, Ibn al Hajj, Ibn al 'Arabiy, Al Qadhiy 'Iyadh, Ibn Rusyd al Hafid, Al Syahibiy.

Dalam bidang Hadits, banyak tokoh-tokoh yang terkenal walaupun negeri Andalus sangat jauh dari al Haramayn (Makkah dan Madinah) yang menjadi pusat hadits. Tokoh-tokoh hadits tersebut diantaranya Baqiy ibn Makhlad, Ibn Wadhdhah, Ibn 'Abd al Barr, Ibn Mufrah, Ibn 'Awnillah, Ibn Khallaf, Ibn al Faradhiy, Ibn al Hajj, Ibn Hazm, Ibn 'Abd al Barr, Razin ibn Mu'awiyah, Al Rusyathiy, Imam Ibn al 'Arabiy, Al Qadhiy 'Iyadh, Ibn Basykuwal, Al Malahiy, Ibn Baqiy, Ibn Sayyid al Nas, Ibn al Zubayr. Dalam bidang Tafsir yang terkenal diantaranya Imam Baqiy ibn Makhlad, Imam ibn al ‘Arabiy, Imam Ibn ‘Athiyah, Imam al Qurthubiy, Imam Abu Hayyan. 
Dalam bidang sejarah dan geografi, wilayah Islam bagian barat juga melahirkan banyak pemikir dan penulis terkenal seperti Abu al Husayn Muhammad ibn Ahmad ibn Jubair al Syathibiy, Ibn Bathutah, Ibn al Khatib. Dalam bidang bahasa dan sastra yang terkenal di andalus diantaranya adalah Ibn Siraj, Al Waffasyiy, Ibn ‘Ayyalun, Ibn Kharuf, Ibn Sayyid al Nas, Ibn Malik.

Tokoh pertama dalam bidang filsafat adalah Ibn Bajjah, Ibn Thufayl, dan Ibn Rusyd. Dalam ilmu kimia dan astronomi adalah 'Abbas ibn Farnas, dalam bidang astronomi adalah Ibrahim ibn Yahya al Naqash. Ahli bidang obat-obatan ada Ahmad ibn Ibas dari Cordova. Dalam bidang kedokteran, terkenal nama Abu Bakr Muhammad ibn 'Abd Malik ibn Zuhr al Isybiliy dan Ibn Khathib, disamping Ibn Thufayl dan Ibn Rusyd yang juga menjadi Filsuf serta Ibn Khatima yang menulis Buku tentang penyakit menular.

Dalam bidang musik dan seni suara, tokohnya al Hasan ibn Nafi' yang dijuluki Zaryab, ia sering tampil dalam acara pertemuan dan jamuan. Disamping sebagai penyanyi, dia juga penggubah lagu. Dalam bidang pembagunan fisik yang paling menonjol adalah pembangunan gedung-gedung seperti pembangunan kota, istana, masjid, pemukiman dan taman-taman. Yang paling megah adalah Masjid Cordova, Istana al Zahra, Istana Ja'fariyah di Saragosa, Tembok Toledo, Istana al Makmun, Masjid Sevilla dan Istana al Hamra di Granada.

\section{c. Pengaruh Ilmu pengetahuan Spanyol Islam terhadap Eropa}

Kemajuan Eropa yang terus berkembang hingga saat ini tidak terlepas dari sumbangan ilmu pengetahuan Islam yang berkembang di Periode Klasik. Tempat yang paling utama bagi Eropa dalam menyerap Peradaban Islam adalah Spanyol baik dalam bentuk hubungan Politik, Sosial, perekonomian maupun Peradaban antarnegara. Orang-orang Eropa menyaksikan kenyataan bahwa Spanyol yang berada di bawah kekuasaan Umat Islam telah jauh meninggalkan negara-negara tetangganya di Eropa terutama dalam bidang pembangunan fisik, sains dan pemikiran. 
Yang paling berpengaruh di Eropa adalah pemikiran Ibn Rusyd yang melepaskan belenggu Taklid dan menganjurkan kebebasan berfikir. Ia mengulas pemikiran Aristoteles dengan cara memikat minat semua orang yang berfikiran bebas. Dia mengedepankan sunnatullah menurut pengertian Islam terhadap Pantheisme dan Anthropomorphisme Kristen. Begitu besar pengaruhnya di Eropa, sehingga di Eropa muncul gerakan Averroeisme (Ibn Rusyd-isme) yang menuntut kebebasan berfikir. Walaupun pihak gereja menolak pemikiran rasional yang di bawah gerakan Averroeisme ini namun berawal dari gerakan inilah pada abad ke $16 \mathrm{M}$ lahirlah reformasi dan pada abad ke $17 \mathrm{M}$ lahir pula rasionalisme di Eropa.

Pengaruh Peradaban Islam, termasuk di dalamnya pemikiran Ibn Rusyd ke Eropa berawal dari banyaknya pemuda-pemuda Krsiten yang belajar ke Universita-universitas Islam di Spanyol, seperti Universitas Cordova, Seville, Malaga, Granada dan Salamanca. Selama belajar di Spanyol, mereka aktif menerjemahkan buku-buku karya ilmuwan-ilmuwan Muslim. Yang menjadi Pusat penerjemahan tersebut adalah Toledo. Setelah pulang ke negerinya, mereka mendirikan sekolah dan universitas yang sama. Universitas pertama didirikan di Eropa adalah Universitas Paris yang didirikan pada tahun $1231 \mathrm{M}$, tiga puluh tahun setelah wafatnya Ibn Rusyd. Sampai pada masa abad Pertengahan baru berdiri 18 buah Universitas di Eropa. Di dalam Universitasuniversitas itulah mereka mengajarkan ilmu-ilmu yang mereka peroleh dari Universitas-universitas Islam seperti ilmu kedokteran, ilmu pasti dan filsafat. Pemikiran filsafat yang paling banyak dipelajari adalah pemikiran Al-Farabi, Ibn Sina dan Ibn Rusyd.

Pengaruh ilmu pengetahuan Islam terhadap Eropa yang sudah berlangsung sejak abad ke $12 \mathrm{M}$ itu akhirnya menimbulkan gerakan kebangkitan kembali (renaissance) pusaka Yunani di Eropa pada abad ke 14 M. Berkembangnya pemikiran Yunani di Eropa kali ini adalah melalui terjemahanterjemahan Arab yang dipelajari dan kemudian diterjemahkan kembali ke dalam bahasa Latin.( Fatmawati, 2010: 403) 
Karya-karya Ibn Rusyd banyak diterbitkan di Eropa, di antaranya di Venesia pada tahun 1481 M,1482 M,1483 M,1489 M dan 1500 M. Bahkan edisi lengkapnya terbit pada tahun 1553 M dan 1557 M. Karya-karyanya juga diterbitkan pada abad ke 16 M di Napoli, Bologna, Lyonms, dan Strasbourg, dan di awal abad ke 17 M di Jenewa. (Badri Yatim, 2010: 109).

Walaupun pada akhirnya umat Islam terusir dari Spanyol dengan cara yang sangat kejam, namun umat Islam telah membidani lahirnya gerakangerakan penting di Eropa. Gerakan-gerakan itu adalah kebangkitan kembali kebudayaan Yunani Klasik (Renaissance) pada abad ke 14 M yang bermula di Italia, gerakan reformasi pada abad ke $16 \mathrm{M}$, Rasionalisme pada abad ke $17 \mathrm{M}$, dan pencerahan (aufklarung) pada abad ke 18 M. (Poeradisastra, 1986: 77).

\section{Sisilia}

\section{a. Masuknya Islam ke Sisilia}

Sisilia adalah sebuah pulau di Laut Tengah yang terletak di sebelah selatan Semenanjung Italia, dipisahkan oleh Selat Messina. Pulau Sisilia bentuknya mendekati segitiga dengan luasnya kira-kira 25.708 KM. Sebelah Utara adalah Teluk Palermo dan sebelah Timur adalah Teluk Catania. Kedua pantai ini agak curam, sedangkan dibagian selatan landai dan datar. Di bagian Belahan Baratnya berbukit-bukit memanjang, sedangkan lereng gunungnya ditumbuhi dengan berbagai jenis hutan dan tanaman keras (Fatmawati, 2010: 425).

Pulau Sisilia terbagi menjadi 3 bagian, yakni Val de Mazara, Val de Noto dan Val de Mone. Di Val de Mazara, Islam menjadi sebuah agama resmi, sedangkan penduduk di bagian Val de Noto dan Val de Mone, kebanyakan penduduknya menganut agama Kristen. Sisilia merupakan salah satu jembatan penyeberangan mengalirnya ilmu pengetahuan Islam ke Eropa. Pulau Sisilia mulai dikuasai oleh Umat Islam pada tahun $652 \mathrm{M}$ dibawah penguasaan Muawiyah ibn Abi Sufyan.

Sebelum Sisilia dikuasai oleh umat Islam, Pulau Sisilia ini berada di bawah kekuasaan Byzantium. Pulau Sisilia dijadikan sebagai markas tentara oleh Byzantium untuk menghadapi orang-orang Islam. Khalifah Muawiyah ibn Abi 
Sufyan telah menguasai Pulau-pulau di Laut Tengah dan mengepung kota Konstantinopel menguasai Afrika Utara.

Pada masa Khalifah Utsman ibn Affan tahun 31 H / 652 M sudah mulai ada usaha untuk menjadikan Sisilia sebagai Wilayah Islam, yang mana Khalifah Utsman memberi tugas kepada Muawiyah ibn Abi Sufyan yang ketika itu menjadi Gubernurnya untuk menyerang Pulau-pulau di Laut Tengah, di antaranya termasuk Pulau Sisilia.

Setelah Muawiyah menjadi khalifah Daulah Bani Umayyah, Muawiyah melakukan penyerangan kedua pada tahun 46 H/667 M. Penyerangan juga dilakukan pada Zaman Khalifah Abdul Malik, dan dilanjutkan oleh anaknya Al Walid ibn 'Abd Malik. 'Abdullah yang merupakan anak dari Musa ib Nushayr seorang Gubernur di Afrika Utara juga melakukan penyerangan ke Sisilia. Namun, penyerangan itu semua belum berhasil menduduki Pulau Sisilia tersebut.

Sisilia baru berhasil ditaklukan, setelah seorang Pangeran dan Komandan angkatan Laut Byzantium yang bernama Commander Euphemius pada tahun 827 M mengundang Sultan ketiga dari Dinasti Bani Aghlabiyyah yang bernama Zidayatullah untuk melakukan intervensi ke wilayah Sisilia. Sultan Zidayatullah menerima undangan tersebut dan mengirimkan pasukannya di bawah pimpinan Panglima Perang Asad ibn al Furat untuk bergabung dengan tentara Euphemius dan mendarat di Mazara pada tahun 827 M. Setelah mereka menghancurkan tentara Byzantium di Mazara, penyerangan dilanjutkan ke Sirrakuse dan selama setahun mengepung kota tersebut. Namun, Panglima Asad diserang oleh wabah penyakit mematikan yang banyak menelan korban jiwa.

Ashbag ibn Wakil yang merupakan seorang Barbar Andalus pada tahun 830 M melanjutkan kembali penyerangan. Tahun $831 \mathrm{M}$, Palermo berhasil direbut oleh pasukan muslimin dan dijadikan sebagai Pusat pemerintahan Islam di Sisilia. Wali pertama yang diangkat adalah Abu Firh Muhammad ibn 'Abdillah. Penaklukan itu terus dilanjutkan oleh Ibrahim ibn 'Abdillah hingga pada akhirnya beliau meninggal setelah masa pemerintahannya berjalan selama 16 tahun. Penyerangan disempurnakan pada masa Gubernur dan Panglima 
Perang Bani Aghlab berikutnya. Sehingga seluruh Sisilia pada tahun 902 M berada di bawah kekuasaan Bani Aghlab.

Dalam buku Dra. Fatmawati, M.Ag dikatakan bahwa Selama masa Dinasti Bani Aghlabiyyah, Sisilia diperintah oleh seorang Gubernur atau amir yang disebut juga dengan Shahib yang jumlahnya mencapai 7 orang secara berturut-turut. Mereka adalah:

a. Abu Firh Muhammad ibn 'Abdillah

b. Abu Aghlab Ibrahim ibn 'Abdillah

c. 'Abbas ibn Fadhl ibn Ya'kub

d. Khafaja ibn Sufyan

e. Ja'far ibn Muhammad

f. Abdullah ibn Ibrahim

g. Ahmad ibn Husayn

Shahib tersebut mempunyai kekuasaan penuh, mempunyai hak otonom dalam hal perang ataupun damai, pembagian harta rampasan, mencetak uang, menentukan pajak, mengangkat Kadi, Badan Koapraja, pengaturan tentang Tanah, dan lain sebagainya.

Penduduk Sisilia ada masa Bani Aghlab terdiri dari berbagai ras, yaitu Bangsa Sisilia, Yunani, Lombard, Arab, Barbar, Persia, dan Negro yang menganut berbagi agama yakni Islam, Kristen dan Yahudi. Bangsa Arab menjadi penguasa, mayoritas Muslim Sisilia berasal dari keturunan Barbar, Arab dan Sisilia. Mayoritas mereka menganut Mazhab Maliki.

Sejalan dengan runtuhnya kekuasaan Dinasti Aghlabiyah di Afrika Utara karena serangan orang Syi'ah, Kekuasaan gubernur Aghlabiyah di Sisilia juga ditumbangkan. Pada tahun 909 M, Ahmad ibn Husyain Gubernur Bani Aghlab yang terakhir ditumbangkan oleh Ali in Ahmad ibn Abi al Fawaris, seorang pendukung Daulah Fathimiyyah yang kemudian menjadi Gubernur Fathimyyah pertama di Sisilia. Dalam masa transisi antara Bani Aghlab dan Fathimyyah ini, di Sisilia terjadi juga pergolakan. Pergolakan tersebut bukan hanya masalah politik saja, namun juga mengarah kepada masalah keagamaan antara Syi'ah dan Sunni. Hingga akhirnya keadaan berhasil dikuasai oleh Daulah Fathimiyyah meskipun masih terdapat pertentangan-pertentangan. 
Semasa pemerintahan gubernur Ibn Abi al Fawaris ini, pada tahun 914 M muncullah di Palermo Ziyadatullah ibn Qurthub yang menentang pemerintahan Dinasti Fathimiyah. Setelah menyingkirkan Ibn Abi al Fawaris, dia merebut Barbarosa dan memaksa wakil Byzantium di Catania untuk membayar upeti kepadanya. Namun, kemudian pemerintah Dinasti Fhatimiyah dapat menangkapnya dan Sisilian aman kembali. Pada tahun 917 M, Khalifah Fhatimiyah melantik Salim ibn Rasyid menjadi Gubernur Sisilia. Setelah memerintah selama dua puluh tahun (917-937 M), Ia digantikan oleh Hasan ibn Ali al Kalbiy. Seorang keturunan Arab Suku Kalb. Hasan ini keudian mendirikan Dinasti Kalbiyah di Sisilia seraya masih menyatakan kesetiannya kepada Dinasti Fathimyah ( Fatmawati, 2010: 428).

Masa pemerintahan dinasti Kalbiyah lebih kurang 90 tahun. Daerah Kristen di Sebelah Utara Pulau Sisilia, Toormina dapat ditaklukkan oleh Hasan. Kemudian nama kota itu dirubah menjadi Mu'izziyah sebagai penghormatan kepada Mu'iz li Dinillah khalifah dari Dinasti Fathimiyah. Penyerangan juga dilakukan ke Italia sehingga beberapa Kota di Italia Selatan membayar Jizyah kepadanya. Kekuasaan Dinasti Kalbiyah di Sisilia berakhir pada tahun 1044 M. Ketika itu gubernur terakhir Kalbiyah yang juga bernama Hasan digulingkan oleh Ibn Hawwas, seorang panglima perangnya sendiri. Ibn Hawwas ini pada tahun $1058 \mathrm{M}$ digulingkan pula oleh Ibn Tuminah seorang bangsawan yang bersekutu dengan bangsa Nurmandia. Persekutuan ini merupakan awal dari kedatangan Bangsa Nurmandia ke Sisilia yang dimulai dari serangan ke Messina tahun 1060 M oleh Roger. Puncaknya adalah penaklukan Palermo pada tahun 1071 M dan Sirakuse pada tahun 1085 M, serta berakhir dengan jatuhnya Noto pada tahun 1091 M. Dengan demikian berakhirlah kekuasaan Dinasti Kalbiyah dan Selanjutnya Silsilia dikuasai oleh orang-orang Nurmandia (Fatmawati, 2010:429).

\section{b. Perkembangan Peradaban Islam di Sicilia dan Pengaruhnya Terhadap Eropa}

Kebudayaan Islam di Sisilia dapat berkembang pada zaman Dinasti Kalbiyah yang berkuasa selama 90 tahun. Pada masa dinasti Aghlabiyah dahulu masih sering terjadi pemberontakan sehingga kebudayaan Islam kurang berkembang. 
Pada masa daulah Fathimiyah mulai dirintis kesejahteraan fisik, namun peradaban belum berkembang. Kebudayaan berkembang pada zaman Dinasti Kalbiyah dan berlanjut pada masa awal kekuasaan Kerajaan Nurmandia.

Pulau Sisilia di masa Dinasti Kalbiyah mengalami kemajuan dalam segala bidang. Amir-amir hidup mewah, kota Palermo dihiasi dengan 150 tempat pemotongan hewan, 300 masjid dan 7000 jama'ah shalat Jum'at dan 300 guru untuk mendidik para pelajar-pelajar. Akibat kemakmuran itu terjadi perpindahan penduduk dari Afrika Utara ke Sisilia secara besar-besaran.

Kebudayaan Islam di Sisilia berkembang pada masa Dinasti Kalbiyah dan awal pemerintahan bangsa Nurmandia. Sarjana-sarjana muncul dari berbagai bidang ilmu. Perkembangan ilmu agama Islam pada masa Dinasti Bani Aghlab lebih menonjol dibanding bidang kajian lainnya. Ilmu Fiqih misalnya sudah membicarakan masalah-masalah yang menyangkut hukuf positif pada masa waktu itu. Para ahli hukum menyesuaikan penafsiran Alqur'An dengan perkembangan zaman. Ummat Islam waktu itu tidak menjalankan hukum Romawi, Yunani atau Kristen, tetapi mereka yang mempengaruhi dunia hukum, termasuk di dalamnya hal-hal yang berkaitan dengan hubungan antar agama. Alqur'an dan hadist dijadikan sebagai sumber pokok hukum Islam. (Fatmawati, 2010: 430).

Selain itu berkembang pula ilmu Kalam, sastra, sejarah, fisika, kedokteran dan ilmu bumi juga ikut berkembang. Dalam ilmu Kalam terkenal 'Abd al Haq ibn Muhammad dan Ibnu Zafar. Bidang sastra diwakili oleh Ali Hamzah al Bashry, dalam bidang sejarah muncul Hajji Khalifah dan Abu Zayd al Ghumariy. Dalam bidang fisika dikenal nama Abu Said Ibrahim dan Abu Bakar as Siqil. Bidang kedokteran tercatat nama Abbul Abbas Ahmad ibn Abd al Idrisi yang mengarang buku Nuzhat al Mustaq fi Ikhtiraj al Afaq. Perkembangan ilmu pengetahuan ini tetap pesat pada zaman Nurmandia, terutama pada masa Raja Roger II yang sangat tertarik dengan matematika, adminitrasi umum dan ilmu bumi.(Musyrifah Sunanto, 160-172).

Dalam bidang perekonomian, yang menjadi sumber utamanya adalah pertanian, perdagangan dan perindustrian. Dalam bidang pertanian mereka 
membangun sistim irigasi Hidrolic dan Shipon yang mereka datangkan dari Persia dan Roma. Karena irigasi baik maka pertanian dan perkebunan menjadi maju. Benih tanaman didatangkan dari Timur, sistem penanamannya pun meniru sistem penanaman yang dilakukan bangsa Arab. Berbagai macam tanaman menjadi tumbuh subur seperti Kurma, anggur, gandum, apel, zaytun kapas, tebu dan lainnya. Dalam bidang perindustrian terdiri dari tambang emas, Sulfur, Belerang, Tawas, industri, Penenunan kain Sutra serta perikanan. Pajak juga menjadi salah satu pendapatan penting yang dipungut dari kalangan muslim maupun non muslim sehingga dapat dapat dibangun Gedung-gedung pemerintahan seperti Masjid, Universitas, Istana di Palermo dan bangunan lainnya.

\section{Perang Salib}

\section{a. Latar belakang terjadinya Perang Salib}

Dalam buku Dra. Fatmawati, M.Ag, Perang Salib merupakan peristiwa sejarah yang sangat berpengaruh terhadap perkembangan kebudayaan dan antar penganut agama Islam dan Kristen. Perang salib ini berlangsung sekitar 200 tahun dalam beberapa gelombang. Latar belakang terjadinya Perang Salib tidak terlepas dari Perang Mazikart (464H/1071 M). Dalam peperangan tersebut Dinasti Saljuk Turki berhasil mengalahkan tentara gabungan Romawi. Sehingga peristiwa ini semakin membuat orang-orang Kristen semakin membenci umat Islam. Apalagi setelah Dinasti Saljuk tersebut berhasil merebut Baitul Maqdis pada tahun 471 M dari kekuasaan Dinasti Fathimiyyah dan bagi umat Kristen ditetapkan beberapa peraturan bagi yang ingin berziarah ke Baitul Maqdis tersebut. Oleh karena itu pimpinan tertinggi umat Kristen, Paus Urbanus II menyerukan agar umat Kristen melakukan Perang Suci untuk membebaskan Palestina dari tangan Umat Islam. Penguasa dan rakyat Kristen Eropa menyambut baik seruan tersebut, hingga terjadilah perang yang berkepanjangan yang di sebut dengan Perang Salib. (Fatmawati, 2010: 432).

Ada beberapa penyebab terjadinya Perang Salib, di antara sebab tersebut yang paling penting adalah: 


\section{Faktor Agama}

Umat Kristen Merebut kota Yerussalem dari kekuasaan Islam yang diawali dari seruan Paus Urbanus II Sebagai Pimpinan Tertinggi dari Umat Kristen. Karena umat Kristen tidak dibebaskan berziarah ke Kota Suci (Yerussalem). Penguasa Islam (Bani Saljuk) menetapkan beberapa peraturan bagi Umat Kristen yang ingin berziarah ke sana. Setiap orang Kristen yang mengikuti peperangan tersebut langsung akan di ampuni dosa-dosanya, oleh karena itu perang tersebut bagi mereka dianggap sebagai Perang Suci.

\section{Faktor Ekonomi}

Masyarakat Eropa sebahagiannya merupakan rakyat miskin yang hidup di bawah tekanan kekuasaan raja yang kejam dan tuan-tuan tanah. Sehingga mereka mengharapkan perubahan terhadap nasib mereka agar menjadi lebih baik jika mereka mengikuti Perang Salib tersebut.

Penyebab lainnya adalah keinginan dari para pedagang-pedagang besar di Kota Venesia, Genoa, dan Pisa untuk menguasai Jalur perdagangan yang terdapat disepanjang Pantai Timur dan Selatan Laut Tengah yang mana ketika itu berada dalam kekuasaan Umat Muslim. Satu-satunya jalan untuk meluaskan dan melancarkan perdagangan mereka adalah dengan mendesak pasukan muslim dari lautan tersebut. Bahkan mereka berani menanggung sebagian dana yang dibutuhkan saat Perang Salib tersebut asalkan rute perdagangan bisa menjadi milik para pedagang itu apabila pihak Kristen memperoleh kemenangan dari Perang Salib tersebut.

\section{Faktor Politik}

Reaksi dari Penguasa dan umat Kristen karena semakin meluasnya wilayah kekuasaan pemerintahan Umat Islam di Asia, Afrika dan Eropa, hal ini merupakan ancaman bagi penguasa-penguasa dan umat Kristen Eropa. Perkembangan dan kemajuan Umat Muslim yang semakin pesat menimbulkan kecemasan bagi umat Kristen oleh karena itu mereka terdorong untuk melancarkan serangan terhadap kekuatan Muslim.

\section{b. Proses terjadinya Perang Salib}

\section{Periode pertama}


Pada musim semi tahun 1095 M, Tentara Salib yang berjumlah sebanyak 150.000 orang Eropa, sebagian besarnya adalah Bangsa Prancis dan Norman berangkat menuju Konstantinopel kemudian terus ke Palestina di bawah pimpinan Godfrey, Bohemond, dan Raymond. Mereka memperoleh kemenangan besar. Pada tanggal 18 Juni 1097 mereka berhasil menaklukan Nicea. Dan pada tahun 1098 M dapat menguasai Raha (Edessa). Di sini mereka mendirikan kerajaan Latin I dengan Baldawin sebagai raja. Pada tahun yang sama mereka dapat menguasai Antiochea dan mendirikan kerajaan Latin II di Timur. Bahemond di lantik menjadi rajanya. Mereka juga berhasil menduduki Baitul Maqdis (15 Juli 1099 M) dan mendirikan kerajaan Latin III dengan rajanya Godfrey. Setelah penaklukan Baitul Maqdis itu, tentara Salib melanjutkan ekspansiya. Mereka menguasai Kota Akka tahun 1104 M, Tripoli tahun 1109 M, Kota Tyre tahun 1124 M. Di Tripoli mereka mendirikan kerajaan Latin IV dengan rajanya adala Raymond (Badri Yatim, 2010:77).

\section{Periode Kedua}

Penguasa Mosul dan Irak, Imanuddin Zanki berhasil menaklukan kembali Aleppo, Hamimah, dan Edessa pada tahun 1144 M. Namun ia wafat dan tugasnya dilanjutkan oleh putranya Nuruddin Zanki dan berhasil merebut kembali Antiochea pada tahun $1149 \mathrm{M}$ dan pada tahun 1151 M dapat merebut kembali seluruh Edessa. Kejatuhan Edessa menyebabkan orang-orang Kristen mengobarkan Perang Salib II. Paus Eugenius III menyerukan perang suci yang disambut positif oleh raja Prancis Louis VII dan Raja Jerman Condrad II. Keduanya memimpin pasukan Salib untuk merebut wilayah Kristen di Syiria. Akan tetapi, gerak maju mereka dihambat oleh Nuruddin Zanki. Mereka tidak berhasil memasuki Damaskus. Louis VII dan Condrad II sendiri melarikan diri pulang ke negerinya (Badri Yatim, 2021:78). Tahun 1174 M Nuruddin Wafat dan pimpinan perang kemudian dipegang oleh Shalah 
Al Din al Ayyubi yang berhasil mendirikan Dinasti Atyyubiyah di Mesir tahun 1175 M. Hasil peperangan Shalah Al-Din yang terbesar adalah merebut kembali Yerussalem pada tahun 1178 M. Dengan demikian, kerajaan Latin di Yerussalem yang berlangsung selama 88 tahun berakhir.

Jatuhnya Yerussalem ke tangan Kaum Muslimin sangat memukul tentara Salib, mereka pun menyusun rencana balasan. Kali ini tentara Salib dipimpin oleh Raja Jerman bernama Frederick Barbarossa, Raja Inggris yang bernama The Lion Hart, dan Raja Prancis yang bernama Philip Augustus. Tahun 1198 M pasukan Salib bergerak dan berhasil merebut Akka, namun Palestina tidak berhasil mereka masuki karena mendapat tantangan berat dari Shalah al-Din. Pada tanggal 2 Nopember 1192 M antara tentara Salib dengan Shalah Al-Din membuat Perjanjian yang disebut dengan Shulh al-Ramlah yang berisi bahwa antara orangorang Kristen yang pergi berziarah ke Baitul Maqdis tidak akan diganggu.

\section{Periode Ketiga}

Pada periode ini, tentara Salib dipimpin oleh Raja Jerman yang bernama Frederick II. Mereka berusaha merebut Mesir dan Palestina. Mereka berhasil menduduki Dimyat pada tahun 1219 M. Raja Mesir dari Dinasti Ayyubiyah ketika itu adalah Malik al Kamil membuat perjanjian dengan Frederick yang isinya antara lain Frederick bersedia melepaskan Dimyat, sementara Al Malik Al Kamil melepaskan Palestina, Frederick menjamin keamanan kaum muslimin di sana dan Frederick tidak mengirim bantuan kepada Krsiten di Syiria. Dalam perkembangan berikutnya, kaum Muslimin berhasil merebut Palestina tahun 1247 M di masa pemerintahan Malik al Shalih penguasa Mesir selanjutnya.

Ketika Mesir dikuasai Dinasti Mamalik yang menggantikan Dinasti Ayyubiyah, pimpinan perang dipegang oleh Baybars dan Qalawun. Pada masa merekalah Akka dapat direbut kembali oleh Kaum Muslimin pada tahun 1291 M. Perang salib terus terjadi bukan hanya di Timur tapi sampai ke Barat, Spanyol bahkan sampai umat Islam terusir 
dari sana. Umat Islam mengalami kerugian meskipun mereka berhasil mempertahankan daerah-daerahnya dari tentara Salib. Akibatnya kekuatan politik umat Islam menjadi lemah dan menjadi terpecah belah. Akhirnya banyak Dinasti-dinasti yang memerdekakan diri dari pemerintahan pusat Abbasiyah di Baghdad.

\section{c. Dampak Perang Salib Terhadap Kebudayaan Islam dan Barat}

Bagi Eropa, Perang Salib tidak mendatangkan keuntungan militer bahkan Eropa telah kehilangan ratusan ribu prajurit dan telah mengeluarkan biaya yang sangat besar untuk keperluan perang tersebut seperti persediaan makanan, obat-obatan, persenjataan dan lain-lainnya. Demikian juga yang dialami oleh tentara Islam. Namun demikian, Perang Salib yang berlangsung lebih kurang dua abad tersebut telah membawa Eropa ke dalam kontak langsung dengan Dunia Islam. Kemajuan orang-orang Timur yang Progresif pada saat itu menjadi daya dorong yang besar bagi pertumbuhan intelektual Eropa Barat sehingga menimbulkan Renaissance di Eropa.

Perang Salib menambah pentingnya posisi Eropa di lapangan perniagaan dan perdagangan. Sebagai hasil dari Perang Salib, orang Eropa dapat mempelajari dan memodifikasi (mengembangkan model) serta mengaplikasikan beberapa temuan penting yang telah dihasilkan oleh orangorang Islam pada masa-masa sebelumnya. Hal ini terutama lebih banyak berkaitan dengan masalah seni, industri, pertanian, dan perdagangan dibandingkan dengan ilmu pengetahuan. Dalam bidang seni, gaya-gaya bangunan dan cara berpakaian Timur mempengaruhi seni gaya bangunan dan berpakaian orang Barat. Demikian pula halnya dalam bidang agrikultural, banyak pasukan Perang Salib yang terbiasa dengan produk Agrikultural (pertanian) Timur. Gula yang paling penting karena gula menjadi makanan paling mewah di Barat. Hal ini berkaitan dengan pasar Eropa baru untuk produk agrikultural Timur. Orang-orang Barat mulai menyadari kebutuhan mereka terhadap barang-barang dari Timur. Karena kepentingan ini, berkembanglah kegiatan perdagangan antara Timur dan Barat. (Fatmawati, 2010:439). 
Bersamaan dengan itu, keperluan transportasi untuk para peziarah dan pasukan Perang Salib, telah meransang kegiatan Maritim (Pelayaran) dan perdagangan internasional. Sejak saat itulah dimulai Aplikasi Kompas (penentu arah) untuk kegiatan maritim. Jarum magnetik memang ditemukan oleh orang Cina, namun pemakaian jarum itu untuk keperluan Navigasi (pelayaran) oleh Islam. Hal ini membuktikan terjadinya difusi kebudayaan Barat dan Timur pada masa Perang Salib. Pada akhirnya, difusi tersebut menjadi landasan bagi terjadinya renaissance di Eropa. (Ajid Thahir, 2004: 142).

\section{CONCLUSIONS (خلاصة | خاتمة)}

Kemajuan Eropa (Barat) memang bersumber dari khazanah ilmu pengetahuan dan metode berfikir Islam yang rasional. Di antara saluran masuknya Peradaban Islam ke Eropa seperti yang sudah dijelaskan di atas adalah melalui Andalusia, Sisilia dan Perang Salib. Ketika Islam mengalami kejayaan di Spanyol, banyak orang Eropa yang datang belajar ke sana kemudian menerjemahkan karya-karya ilmiah umat Islam. Hal ini dimulai sejak abad ke 12 M, setelah mereka pulang ke negeri masing-masing, mereka mendirikan universitas dengan meniru pola Islam dan mengajarkan ilmu-ilmu yang dipelajari di Universitas-universitas Islam itu. Dalam perkembangan selanjutnya, keadaan ini melahirkan kebangkitan renaissance (kebangkitan kembali), reformasi, rasionalisme dan Pencerahan (Aufklarung) di Eropa. Begitu juga dengan keberadaan Islam di Sisilia dan pengaruh dari Perang Salib yang pada akhirnya membawa Eropa kepada zaman kemajuan.

\section{BIBILIOGRAPHY (قائمة المراجع)}

\section{References :}

Ali, K. (2003). Sejarah Islam (Tarikh Pra Modern). Jakarta: PT Raja Grafindo Persada Fatmawati.(2010). Sejarah Peradaban Islam. Batusangkar: STAIN Batusangkar Press Harun, Maidir dan Firdaus. (2001). Sejarah Peradaban Islam. Padang: IAIN Press May, Asmal. (2016). Peradaban Islam dalam Lintasan Sejarah. Jakarta: Citra Harta Prima

Poeradisaatra, (1986). Sumbangan Islam Kepada Ilmu dan Peradaban Dunia. Jakarta: $\mathrm{P} 3 \mathrm{M}$ 
Salim, Abdullah. (1980). Sumbangsih Andalusia kepada Dunia Barat. Kendal: CV Abdillah Putra

Sunanto, Musyrifah. (2003). Sejarah Islam Klasik (Perkembangan Ilmu Pengetahuan Islam). Jakarta: Kencana.

Syukur, Fatah. (2009). Sejarah Peradaban Islam. Semarang: PT Pustaka Rizki Putra

Thahir, Ajid (2004). Perkembangan Peradaban di Kawasan Dunia Islam. Jakarta: Raja Grafindo Persada.

Yatim, Badri. (2010). Sejarah Peradaban Islam (Dirasah Islamiyah II). Jakarta: Rajawali Press 